\title{
Extended Release Capsule, Hard Dosage Form
}

National Cancer Institute

\section{Source}

National Cancer Institute. Extended Release Capsule, Hard Dosage Form. NCI

Thesaurus. Code C158214.

A capsule, covered with a rigid outer shell, that is designed to release active and/or inert ing redient(s) at a controlled, prolonged rate to reduce dosing frequency. 